\title{
STRENGTHENING THE EU'S RESPONSE TO ENERGY POVERTY
}

\author{
Audrey Dobbins ${ }^{1 *}$, Francesco Fuso Nerini², Paul Deane ${ }^{3}$, Steve Pye ${ }^{4}$ \\ ${ }^{1}$ Institute of Energy Economics and Rational Energy Use, University of Stuttgart, Germany \\ ${ }^{2}$ Unit of Energy Systems Analysis, KTH - Royal Institute of Technology, Sweden \\ ${ }^{3}$ MaREI Centre, Environmental Research Institute, University College Cork, Ireland \\ ${ }^{4}$ UCL Energy Institute, University College London, UK \\ *audrey.dobbins@ier.uni-stuttgart.de
}

\section{Energy poverty in the European Union poses a distinctive challenge across Member States, and requires tailored and targeted action. EU policy makers need to strengthen the response to energy poverty and engender action across Member States, moving beyond the focus on vulnerable consumers in energy markets.}

It is estimated that in 2018 more than 50 million people were experiencing energy poverty in Europe ${ }^{1}$.

Energy poverty is a multi-dimensional concept but can be thought of as a situation where households are unable to adequately meet their energy needs at affordable cost, and is caused by a combination of interrelated factors including low income, high energy prices, poorly insulated buildings and inefficient technologies and sometimes limited access to clean and affordable energy sources ${ }^{2,3}$. Energy poverty is linked to wider health issues, including excess winter death and poor mental health ${ }^{4,5}$. Energy poor households may also face disproportionately higher energy costs due to lower levels of access to competitive tariffs and other energy market benefits. However, the issue has only recently gained meaningful recognition by the European policy community.

The concept of energy poverty is intertwined with but distinct from that of vulnerable consumers (Table 1). Member States identify vulnerable consumers based on different criteria. Their definition and protection is tasked to regulators as per EU legislation ${ }^{6,7}$, where protective measures are typically more short-term, address acute access issues, and are limited to electricity and gas supply ${ }^{2}$. Energy poverty goes 
beyond this to encompass all household energy fuels, with a focus on affordability for adequate energy provision and on addressing the underlying drivers of the problem ${ }^{2}$.

\section{Table 1: The distinction between vulnerable consumers and energy poverty ${ }^{2}$}

While action on vulnerable consumers has been mandated in legislation, formal recognition of and action on energy poverty has largely been confined to individual Member States (only five Member States recognise the concept), reflecting subsidiarity concerns. The Commission's proposal, "Clean Energy for All Europeans" package (CEP), has gone further than previous legislation by recommending changes across a range of policies that integrate consideration of energy poverty ${ }^{8,9}$. For example, in the proposed revision of the Electricity Directive, Member States will be required to assess the number of households in energy poverty and take into account the necessary energy services needed to guarantee basic standards of living ${ }^{11}$. Member States that have a significant number of households in energy poverty must formulate national objectives to reduce energy poverty ${ }^{10}$. Furthermore, the new Directive on the Energy

Performance in Buildings makes a specific requirement for energy efficiency actions in buildings to target energy poverty ${ }^{11}$.

These provisions will bring the issue more concretely into European legislation, but will afford flexibility for Member States to determine the significance of and how to address energy poverty. Ongoing negotiations about more prescriptive action have run into difficulty, with some Member States reluctant about including energy poverty in legislation if it places obligations to define and undertake action ${ }^{12}$. A key question remains as to whether the current and proposed recognition of energy poverty in legislation is an adequate response at the EU level, which if in place, could drive action across Member States.

\section{The challenge of a diverse Union}

The concept of energy poverty was not recognized in European legislation until 2009, leading to the requirement for Member States to define 'vulnerable consumers' ${ }^{13}$. The absence of guidance on what 
constitutes a vulnerable consumer resulted in divergent interpretations leading to an inadequate and fragmented level of protection across some Member States².

This experience and the limited specific legislative focus on energy poverty to date suggests that the absence of a common definition for energy poverty could also risk undermining broader European-wide action $^{2,13}$. Gaining consensus on such a definition is inherently difficult given the diversity of Member States' level of recognition, circumstances and experiences ${ }^{14}$. However, a common understanding would support both the recognition of the problem in all Member States and EU-wide coordination to address the problem.

The extent and magnitude of the vulnerability to energy poverty varies across Member States (Figure 1). The diversity between national energy systems, building stock and tenure, policy approach, income levels and climate need to be taken into consideration when addressing this problem domestically ${ }^{15}$. In addition, the country-led approach to energy poverty differs markedly, with some Member States are at a more advanced stage in the policy debate ${ }^{16}$. These factors pose a challenge in addressing energy poverty; on the one hand, the significance of the issue calls for European leadership, while on the other, this heterogeneity poses a challenge to EU policy-making in terms of finding the balance between centralised and devolved Member State subsidiarity.

Figure 1: Vulnerability to Energy Poverty across EU Member States (2016) ${ }^{22}$. Percentage of the population in each Member State that is at-risk-of-poverty with an inability to keep home adequately warm.

\section{Existing action across Member States}

Existing policy measures addressing the issue vary considerably across countries, but can be classified in three common categories (Table 2). Two-thirds of Member States provide measures aimed at offering targeted support to protect vulnerable consumers and address energy poverty. Basic protection for vulnerable consumers, such as financial transfers or disconnection protection, is provided in many Member States, but is absent in $20 \%$. Financial transfers offer short-term financial relief to help 
households meet energy costs and are typically distributed through the social welfare system. Half of all Member States provide financial assistance as part of general welfare support, while the remainder provide targeted energy or heating payments ${ }^{17}$, however there is overlap between the two. In Denmark and the Netherlands, this financial support is coupled with investment into improving energy efficiency, helping tackle the underlying affordability issue ${ }^{2}$. Social tariffs provide a specific tariff, often below the market price, to a group of consumers to ensure energy prices are affordable and cover either electricity, gas or both. While these are being phased out due to market liberalisation, they remain important mechanisms in Belgium, Cyprus, Greece, Portugal, Romania and Spain ${ }^{17}$.

Disconnection safeguards ensure that households can maintain a connection to energy services for a period after energy bills are not paid. While the majority of Member States have some type of prohibition in place as per EU legislation (e.g., disconnection is not permitted during winter or year-round for vulnerable or all consumers), almost a third do not provide any specific protection for vulnerable consumers. There is also large disparity with notification periods for disconnections varying from 2 to 200 working days, with often only limited support provided to vulnerable consumers. These provisions work best in combination with complementary measures such as consumer engagement, which encompasses a diverse range of measures to inform and engage consumers on their energy expenditure. Consumer engagement measures include providing enhanced information on billing (e.g., in North West Europe) and utility codes of conduct when engaging with consumers (e.g., in Belgium, United Kingdom $)^{17}$.

Finally, energy efficiency measures, even if not always directly targeted at energy poverty, are a critical means for reducing energy consumption and increasing thermal comfort, while addressing the underlying structural causes of energy poverty. Targeted energy efficiency for buildings and/or appliances is applied in half of all Member States with the majority aimed at financing retrofits through grants or loans ${ }^{2}$. The magnitude and varying aspects of energy poverty experienced in each Member State will require a differentiated response, putting emphasis on solutions targeting the specificities of the problem. However, 
some common provisions across the EU could also allow energy consumers to benefit from minimum protection.

Table 2: Vulnerability to energy poverty, definitions of energy poverty and vulnerable consumers, and protective measures implemented across Member States $(2016)^{2,17,22}$.

\section{Strengthening the policy agenda}

The EU has taken steps to integrate the concept of energy poverty into the CEP, which in turn should encourage further recognition and targeted action at the Member State level. While some Member States are proactive in deploying a variety of measures, the broader response needs to be strengthened. To do this, the EU should consider four key areas for action.

Prescriptive measures. The EU has to manage a balance between lighter touch proposals that respect subsidiarity, and stronger European-wide measures that require widespread support. Proposed legislation requires Member States to include national indicative objectives to reduce energy poverty only in cases where a 'significant' number of households are impacted by energy poverty. This essentially allows Member States to make different interpretations on the significance of the issue. Instead, all Member States should be required to act on the issue through annual reporting on the implementation of action plans to reduce energy poverty, or be required to provide a rationale for not taking action. Certain measures should be included in EU legislation as minimum requirements. For example, consumers should be protected from disconnection from basic energy services by setting a minimum number of days between energy bill non-payment and disconnection. Stronger mandates in energy market legislation should provide clear procedures on how Member States should engage vulnerable consumers on their rights, and provide information on financing options for renewable and energy efficiency technologies. However, other measures, particularly those focused on energy poverty, must be tailored to local context, and reflect the subsidiarity principle in specific policy areas. For example, financial assistance for specific heating technologies and fuels (e.g., district heating) would be more useful in particular situations. To guide Member States in selecting and implementing effective and relevant measures, coordination and a 
collection of best practices will be useful. Such information will likely be collated via the recently established European Energy Poverty Observatory (EPOV). This growing body of information will support Member States to implement effective measures.

Definitions. The Commission has not provided a formal definition of energy poverty, despite calls from the policy ${ }^{18,19}$ and research communities ${ }^{3,13,14}$, opting rather for a general description ${ }^{8}$. Given the reluctance of some Member States to recognise the issue, the widely differing national contexts and experiences, and the well-versed debate on appropriate metrics, this is not surprising ${ }^{14,20}$. Yet establishing a definition for energy poverty, separate from vulnerable consumers, is important for developing a common basis from which Member States can take action. Years of academic debate shows there is no perfect definition, but pragmatism is needed. A common definition should encompass energy affordability concerns based on the adequacy of meeting household energy requirements and will stimulate recognition of the significance of the issue, and reinforce the need for action. At the same time, what constitutes a vulnerable consumer should be defined based on a combination of the socio-economic situation (e.g., health, age) and energy-related structural circumstances (e.g., building efficiency) thereby reflecting affordability, access, and participation in energy markets ${ }^{2}$.

A definition would provide a basis for developing metrics that enable measurement and monitoring. Recent work has shown that a range of metrics might need to be operationalised to fully capture the extent and nature of energy poverty across Europe ${ }^{20}$. Having both a definition and set of metrics at the EU level could provide a minimum level of recognition, with Member States continuing to develop their own metrics and measures subject to national circumstances ${ }^{2}$.

Data. Data are needed to enhance our understanding of energy poverty, monitor the issue over time and plan adequate policy responses. Similarly, the EU could steer the decision on the types of data to be collected, for instance better detail on building stock related income and energy consumption data and higher spatial resolution on affordability concerns facilitated through statistical agencies such as Eurostat. The EPOV provides a promising platform for gathering information and data, developing indicators and 
monitoring progress on energy poverty in the EU. Similarly, the EPOV can provide assistance to Member States on selecting indicators, separate from those on the EU level, appropriate for their national contexts. Strategic coordination. Given the multi-dimensional nature of energy poverty, a cross-cutting response is needed across social, consumer and energy policy. This means clearly integrating energy poverty into the mandate and budget of relevant policy making bodies as well as any respective legislation. One useful mechanism to facilitate this integration could be through the impact assessment process, which already has some provision in the guidance for the evaluation of distributional impacts ${ }^{21}$. While the EU pushes the agenda forward, Member State actors will need to be engaged in order to implement action. The EU should draw on the experience of Member States with a policy track record who could share their knowledge and experiences. The research community can play a role by generating new insights to better understand the drivers of energy poverty, and the necessary data and analysis to tackle the problem. With the establishment of the EPOV and the European ENGAGER energy poverty network, the research community is primed to help fill key research gaps, such as furthering the understanding of energy poverty in different contexts, indicator development and stakeholder recognition.

\section{Towards concrete action}

As European decision makers revise and launch new energy and climate legislation, there is an opportunity to strengthen action to address energy poverty. Whilst there is increasing recognition that energy poverty needs to be addressed differently across Member States, EU leadership is needed to solidify legislation and catalyse action. If absent, there is a risk that this challenge will continue to be poorly recognised, and will not be targeted with effective action that differentiates household needs and capacity.

\section{Data availability}

All data is publically available in the sources listed.

\section{References}

1. Thomson, H. and Bouzarovski, S. Addressing Energy Poverty in the European Union: State of Play and Action. EU Energy Poverty Observatory (2018). 
2. Pye, S., Dobbins, A., Baffert, C., Brajković, J., Grgurev, I., De Miglio, R., Deane, P. Energy poverty and vulnerable consumers in the energy sector across the EU: analysis of policies and measures. (2015).

3. EPEE. Tackling fuel poverty in Europe. Recommendations Guide for Policy Makers. European Fuel Poverty and Energy Efficient Project. (2009).

4. Liddell, C., Morris, C., Thomson, H. \& Guiney, C. Excess winter deaths in 30 European countries 1980-2013. A critical review of methods. J Public Health (Oxf) 38, 806-814 (2015).

5. Braubach M, Jacobs DE and Ormandy D. Environmental burden of disease associated with inadequate housing. Copenhagen. WHO Regional Office for Europe, 2011. (2011).

6. European Parliament. Directive 2009/72/EC of the European Parliament and of the Council of 13 July 2009 concerning common rules for the internal market in electricity and repealing Directive 2003/54/EC (2009).

7. European Parliament. Directive 2009/73/EC of the European Parliament and of the Council of 13 July 2009 concerning common rules for the internal market in natural gas and repealing Directive 2003/55/EC (2009).

8. European Commission. Proposal for a directive of the European Parliament and of the Council on common rules for the internal market in electricity (recast). COM(2016) 864 final/2 (2016).

9. European Commission. Commission proposes new rules for consumer centred clean energy transition (2016).

10. European Commission. Proposal for the Regulation of the European Parliament and of the Council on the Governance of the Energy Union, amending Directive 94/22/EC, Directive 98/70/EC, Directive 2009/31/EC, Regulation (EC) No 663/2009, Regulation (EC) No 715/2009, Directive 2009/73/EC, Council Directive 2009/119/EC, Directive 2010/31/EU, Directive 2012/27/EU, Directive 2013/30/EU and Council Directive (EU) 2015/652 and repealing Regulation (EU) No 525/2013. 2016/0375 (COD) (2016)

11. European Commission. DIRECTIVE (EU) 2018/844 OF THE EUROPEAN PARLIAMENT AND OF THE COUNCIL of 30 May 2018 amending Directive 2010/31/EU on the energy performance of buildings and Directive 2012/27/EU on energy efficiency (2018).

12. Council of the European Union. Interinstitutional File: 2016/0375 (COD). Proposal for a REGULATION OF THE EUROPEAN PARLIAMENT AND OF THE COUNCIL on the Governance of the Energy Union, amending Directive 94/22/EC, Directive 98/70/EC, Directive 2009/31/EC, Regulation (EC) No 663/2009, Regulation (EC) No 715/2009, Directive 2009/73/EC, Council Directive 2009/119/EC, Directive 2010/31/EU, Directive 2012/27/EU, Directive 2013/30/EU and Council Directive (EU) 2015/652 and repealing Regulation (EU) No 525/2013. Preparation of third trilogue. Available at http://data.consilium.europa.eu/doc/document/ST-8536-2018-INIT/en/pdf (2018).

13. Bouzarovski, S. Energy Poverty. (Dis)Assembling Europe's Infrastructural Divide (Palgrave Macmillan; Springer [Distributor], New York, Secaucus, 2018).

14. Thomson, H., Snell, C. \& Liddell, C. Fuel poverty in the European Union: a concept in need of definition? People, Place and Policy 10/1, 5-24 (2016).

15. Bouzarovski, S. \& Tirado Herrero, S. The energy divide: Integrating energy transitions and regional inequalities in energy poverty trends. European Urban and Regional Studies 24, 69-86 (2017).

16. Baker, K.J., Mould, R. \& Restrick, S. Rethink fuel poverty as a complex problem. Nature Energy 3, 610-612 (2018). 
17. Dobbins, A. et al. Measures to protect vulnerable consumers in the energy sector: an assessment of disconnection safeguards, social tariffs and financial transfers (2016).

18. EESC. Opinion of the European Economic and Social Committee on Energy poverty in the context of liberalisation and the economic crisis. (Exploratory opinion). TEN/420. (Brussels, 2010).

19. European Commission. Working Paper on Energy Poverty. Available at https://ec.europa.eu/energy/sites/ener/files/documents/Working\%20Paper\%20on\%20Energy\%20Pove rty.pdf (2016).

20. Rademaekers, K. et al. Selecting Indicators to Measure Energy Poverty. Under the Pilot Project 'Energy Poverty - Assessment of the Impact of the Crisis and Review of Existing and Possible New Measures in the Member States. Framework Contract ENER/A4/516-2014. Available at http://trinomics.eu/project/selecting-indicators-to-measure-energy-poverty/ (2016).

21. European Commission. Better regulation: guidelines and toolbox. Chapter III: Impact assessment. Available at https://ec.europa.eu/info/law/law-making-process/planning-and-proposing-law/betterregulation-why-and-how/better-regulation-guidelines-and-toolbox_en.

22. EUROSTAT. Inability to keep home adequately warm - EU-SILC survey. Available at https://ec.europa.eu/eurostat/web/products-datasets/product?code=ilc_mdes01 (2016).

\section{Acknowledgements}

The research in this paper benefited from funding provided through the FP7 INSIGHT_E project (www.insightenergy.org, EC grant agreement no. m612743), and collaboration with the members of the consortium.

\section{Author contributions}

All authors co-wrote the paper.

\section{Competing interests}

The authors declare no competing financial or non-financial interests. 
Figure 1: Vulnerability to Energy Poverty across EU Member States (2016) ${ }^{22}$. Percentage of the population in each Member State that is at-risk-of-poverty with an inability to keep home adequately warm. 
Table 1: The distinction between vulnerable consumers and energy poverty ${ }^{2}$

\begin{tabular}{|l|l|l|}
\hline Concepts & Vulnerable Consumer & Energy Poverty \\
\hline Energy sources & $\begin{array}{l}\text { Includes individuals at risk of or in energy } \\
\text { poverty, but also a broader group of specific } \\
\text { consumers such as recipients of social welfare } \\
\text { or those with disability and/or health issues } \\
\text { who may be at a disadvantage in the } \\
\text { purchasing and use of energy }\end{array}$ & $\begin{array}{l}\text { Commonly understood to describe a situation } \\
\text { where individuals or households are not able to } \\
\text { adequately heat or purchase other energy services at } \\
\text { affordable cost }\end{array}$ \\
\hline Timeframe & $\begin{array}{l}\text { Focus on electricity and gas, based on } \\
\text { legislative requirements (e.g., Internal Energy } \\
\text { Market Directives) }\end{array}$ & $\begin{array}{l}\text { All household energy sources, possibly including } \\
\text { for mobility }\end{array}$ \\
\hline Target group(s) & $\begin{array}{l}\text { Shorter-term curative focus on consumer } \\
\text { protection and continued access to gas and } \\
\text { electricity }\end{array}$ & $\begin{array}{l}\text { Specific disadvantaged groups, such as those } \\
\text { that receive social welfare or have health } \\
\text { and/or disability issues } \\
\text { efficiency, low incomes and high energy costs }\end{array}$ \\
\hline Implementing agent & $\begin{array}{l}\text { Typically the regulator or consumer protection } \\
\text { agencies, utilities, and government } \\
\text { affordability issues }\end{array}$ & $\begin{array}{l}\text { A broader range of stakeholders such as } \\
\text { government, consumer groups and non- } \\
\text { governmental organisations, not just regulators and } \\
\text { utilities }\end{array}$ \\
\hline
\end{tabular}


Table 2: Vulnerability to energy poverty, definitions of energy poverty and vulnerable consumers, and protective measures implemented across Member States $(2016)^{2,17,22}$.

\begin{tabular}{|c|c|c|c|c|c|c|c|c|c|c|}
\hline \multirow[b]{3}{*}{ 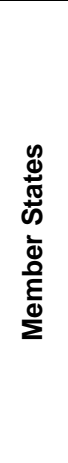 } & \multirow[b]{3}{*}{ 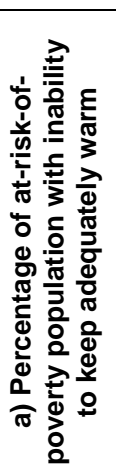 } & \multirow[b]{3}{*}{ 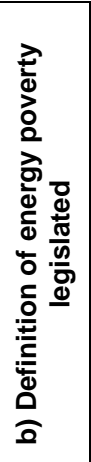 } & \multirow[b]{3}{*}{ 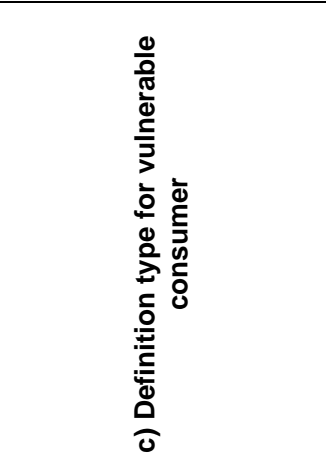 } & \multicolumn{7}{|c|}{ Protective measures } \\
\hline & & & & \multicolumn{3}{|c|}{$\begin{array}{l}\text { d) Financial support } \\
\text { measures }\end{array}$} & \multicolumn{2}{|c|}{$\begin{array}{l}\text { e) Disconnection } \\
\text { safeguards }\end{array}$} & \multirow[b]{2}{*}{ 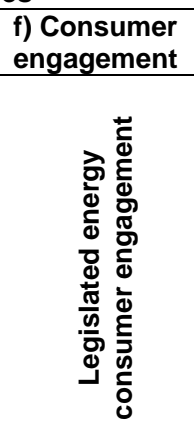 } & \multirow[b]{2}{*}{ 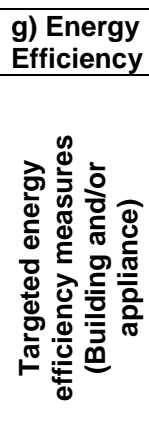 } \\
\hline & & & & 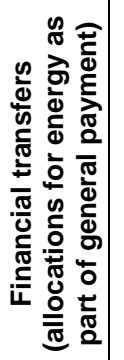 & 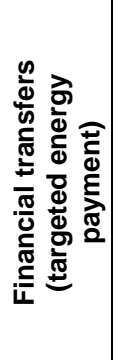 & 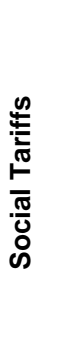 & 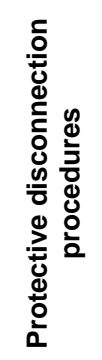 & 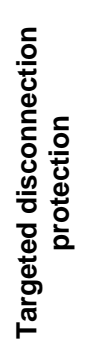 & & \\
\hline AT & 9 & & $\begin{array}{l}\text { Range of socio- } \\
\text { economic groups }\end{array}$ & $x$ & $x$ & & & & $x$ & $x$ \\
\hline $\mathrm{BE}$ & 16 & & $\begin{array}{l}\text { Range of socio- } \\
\text { economic groups }\end{array}$ & $\mathrm{x}$ & $x$ & $x$ & $x$ & & $x$ & $x$ \\
\hline BG & 62 & & Receipt of social welfare & $x$ & $x$ & & & & & \\
\hline CY & 49 & $\mathrm{x}$ & Receipt of social welfare & & & $\mathrm{x}$ & & $x$ & $x$ & $x$ \\
\hline $\mathbf{C Z}$ & 13 & & Disability and/or health & & & & & & & \\
\hline $\mathrm{DE}$ & 12 & & Receipt of social welfare & $x$ & & & & & $x$ & $x$ \\
\hline DK & 8 & & Receipt of social welfare & $x$ & $x$ & & & $x$ & $x$ & $x$ \\
\hline EE & 6 & & Receipt of social welfare & & & & & $x$ & & \\
\hline ES & 23 & & $\begin{array}{l}\text { Range of socio- } \\
\text { economic groups }\end{array}$ & & $\mathrm{x}$ & $\mathrm{x}$ & $\mathrm{x}$ & $\mathrm{x}$ & $x$ & $x$ \\
\hline FI & 4 & & Receipt of social welfare & $x$ & & & $x$ & $x$ & & \\
\hline FR & 14 & $x$ & $\begin{array}{l}\text { Energy affordability (low } \\
\text { income/ high } \\
\text { expenditure) }\end{array}$ & $\mathrm{x}$ & $\mathrm{x}$ & $x$ & & $x$ & $x$ & $x$ \\
\hline GR & 53 & & $\begin{array}{l}\text { Range of socio- } \\
\text { economic groups }\end{array}$ & & & $\mathrm{x}$ & $x$ & $x$ & & $x$ \\
\hline HR & 22 & & Receipt of social welfare & $x$ & $x$ & & $x$ & & & \\
\hline HU & 23 & & Receipt of social welfare & & $x$ & & $x$ & $x$ & & \\
\hline IE & 15 & $x$ & Disability and/or health & $x$ & $x$ & & & $x$ & $x$ & $x$ \\
\hline IT & 32 & & $\begin{array}{l}\text { Energy affordability (low } \\
\text { income/ high } \\
\text { expenditure) }\end{array}$ & & $x$ & & & & $x$ & $x$ \\
\hline LT & 30 & & Receipt of social welfare & $x$ & $x$ & & & $x$ & & \\
\hline LU & 4 & & Receipt of social welfare & $x$ & $x$ & & & & & \\
\hline LV & 23 & & $\begin{array}{c}\text { Not available/ Under } \\
\text { discussion }\end{array}$ & & & & $\mathrm{x}$ & & $x$ & \\
\hline MT & 14 & & Receipt of social welfare & $x$ & & & & & & $x$ \\
\hline $\mathbf{N L}$ & 8 & & Disability and/or health & & & & $x$ & $x$ & & $x$ \\
\hline $\mathbf{P L}$ & 17 & & Receipt of social welfare & & & & & $\mathrm{x}$ & $x$ & \\
\hline PT & 43 & & Receipt of social welfare & & & $\mathrm{x}$ & & & $\mathrm{x}$ & \\
\hline RO & 26 & & $\begin{array}{l}\text { Range of socio- } \\
\text { economic groups }\end{array}$ & $x$ & $x$ & $\mathrm{x}$ & $x$ & $x$ & $x$ & \\
\hline SE & 5 & & $\begin{array}{l}\text { Energy affordability (low } \\
\text { income/ high } \\
\text { expenditure) }\end{array}$ & & & & & $\mathrm{x}$ & $\mathrm{x}$ & \\
\hline SI & 14 & & Receipt of social welfare & & & & & & $x$ & \\
\hline SK & 17 & $x$ & Disability and/or health & & & & $x$ & $x$ & & $x$ \\
\hline UK & 14 & $\mathrm{x}$ & $\begin{array}{l}\text { Range of socio- } \\
\text { economic groups }\end{array}$ & $\mathrm{x}$ & $x$ & & & $x$ & & $x$ \\
\hline \multicolumn{11}{|c|}{$\begin{array}{l}\text { a) The vulnerability to energy poverty displayed in Figure } 1 \text { is represented through the percentage of at-risk-of-poverty population } \\
\text { with the inability to keep adequately warm }{ }^{22} \text {. b) A definition for energy poverty is officially legislated in five Member States. c) Member } \\
\text { States define vulnerable consumers along different characteristics. Protective measures include d) financial support measures in the } \\
\text { form of financial transfers, provided either as a general welfare payment that includes energy costs, targeted energy payments, or } \\
\text { social tariffs (The social tariff in France was removed in } 2017 \text { and replaced with an "Energy Cheque" in 2018.); e) disconnection } \\
\text { protections including general procedures (where the recommended minimum } 40 \text { days between notice and disconnection are given) } \\
\text { and targeted protection (seasonal or year-round disconnection prohibition for vulnerable consumers); f) consumer engagement; and } \\
\text { g) targeted energy efficiency measures }{ }^{2,17} \text {. }\end{array}$} \\
\hline
\end{tabular}

